\title{
高速道路の最適流入制御への進化計算手法の適用*
}

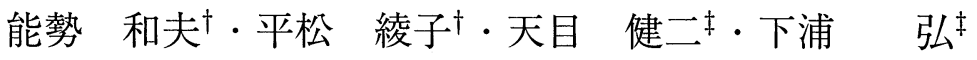

\section{Application of Evolutionary Computation to Optimal On-ramp Traffic Control*}

\author{
Kazuo Nose ${ }^{\dagger}$, Ayako Hiramatsu ${ }^{\dagger}, K_{\text {Kenji Tenmoku }}^{\ddagger}$ and Hiroshi Shimoura ${ }^{\ddagger}$
}

\begin{abstract}
In this paper, the numerical solution method of an on-ramp traffic control problem is discussed from the viewpoint of the application of evolutionary computation. The problem is formulated as a discrete-time nonlinear optimal control problem. The optimal control problem is then transferred to an optimization problem with successive constraints. A parallel-adaptive genetic algorithm is proposed to obtain the numerical solution of the problem. A real-time practical control method is also proposed. Numerical simulations for assessing the performance of the proposed methods are performed using observed data of Hanshin Expressway. As a result, the proposed method obtains the solution at comparatively small generations. This means shortening the calculation time, and is useful for the real-time control. Moreover, it is shown that the proposed real-time control is effective to reduce heavy congestion on the expressway.
\end{abstract}

\section{1. まえがき}

近年，都市での慢性的な道路渋滞が問題になっており， ITSの分野では, 安全, 円滑という視点から種々の渋滞 緩和策が検討されている. 都市内高速道路については, 現在, 過度の交通需要がある場合に, 管理者の判断で流 入ランプの閉鎖が行われている程度で, 必ずしもきめ細 かで効率的な流入制御が行えているとはいえない.また, 環境問題の点からも, 都市内の交通はより制御される方 向にある．具体的には，国道 43 号線におけるトラック の阪神高速道路湾岸線への迂回, 東京都によるディーゼ ル車の流入規制や都心乗り入れ車両に対する課金の検討 などである.このような社会的課題に対するシステム工 学的な解決策として, ITS を利用したきめ細かな交通流 制御に期待が寄せられている。

本論文は, 都市内高速道路の流入ランプにおける交通 流制御問題のシステム工学的解法を検討したものである.

\footnotetext{
* 原稿受付 2001 年 7 月 4 日

$\dagger$ 大阪産業大学 工学部 Faculty of Engineering, Osaka Sangyo University ; 3-1-1, Nakagaito, Daito, Osaka 5748530, JAPAN

‡ 住友電気工業 (株) Sumitomo Electric Industries, Ltd.; 1-1-3 Shimaya, Konohana-ku, Osaka 554-0024, JAPAN Key Words: expressway, on-ramp traffic control, discretetime nonlinear dynamical system, parallel-adaptive genetic algorithm, real-time control.
}

流入制御問題のシステム工学的な解法としては, 定常交 通流を対象とした線形計画法による解法 [1-6], 非定常 交通流に対する線形計画法による解法 $[7,8]$, 非定常交通 流に対する 2 次計画法を用いた解法 [9] などが研究され ている.しかしながら, 高速道路のマクロ的な交通流は, 本質的に動的な非線形方程式で記述される $[10,11]$. した がって, より効果的な制御を施すためには，交通流の非 線形特性を考慮する必要があると考える。

そこで本論文では, 交通流を本来の非線形動的システ ムとして取り扱って高速道路流入制御問題を考え，その 数值解法を提案する。まず，流入制御問題を離散時間型 非線形最適制御問題として定式化する。しかし, 最適制 御問題は解析的には解けないので, 制御問題を最適化問 題に定式化し直し, 探索アルゴリズムによって最適解を 求める. その結果, 流入ランプの最適流入量が数值的に 求まる。また，探索アルゴリズムとして，探索効率向上 を目指した並列適応型遺伝的アルゴリズムを示す。さら に，最適制御の実用化を想定し，短期間の最適制御問題 を繰り返し解くリアルタイム制御方式についても言及す る。なお，本論文と同様に，流入制御に遺伝的アルゴリ ズムを用いた研究も報告されている [12]. ただし，そこ では，ロードプライシング法との併用の観点から制御が 論じられ，最適制御問題は明確には定式化されていない. また，遺伝的アルゴリズムには標準的なアルゴリズムが 
用いられている.

本論文の構成は以下のようである. 2. で交通流の数式 モデルの作成，最適制御問題の定式化およびその最適化 問題への変換を行う. 3. で並列適応型遺伝的アルゴリズ ムを示す．4.でリアルタイム制御方式について述べる. 5. で提案手法の妥当性を数值シミュレーションによって 検証する．6.でまとめと今後の展望を述べる．

\section{2. 交通流の数学モデルと最適制御問題}

\section{1 交通流モデル}

交通流には，交通量（単位時間に通過する車の台数） $Q$ と密度（道路単位長さあたりの車の台数） $K$ との 間に Fig. 1 に示すような $Q-K$ 曲線とよばれる二次曲 線に似た関係が存在する．車の走行速度と密度の関係 $v=V(K)$ が Fig. 2 に示すような直線になる場合，すな わち, $V(K)=v^{f}\left(1-K / K^{\max }\right)$ のとき，交通量は

$$
Q=Q(K)=v^{f} K\left(1-\frac{K}{K^{\max }}\right)
$$

となり， $Q-K$ 曲線は二次曲線となる。 $v^{f}$ は自由走行 速度とよばれている。(1) 式は, 交通量が最大 $Q^{\max }$ と なる密度 $K^{o p t}$ が存在し; それらは $Q^{\max }=v^{f} K^{\max } / 4$, $K^{o p t}=K^{\max } / 2$ であることを示している．区間 $\left[0, K^{o p t}\right]$ が非渋滞時，区間 $\left[K^{o p t}, K^{\max }\right]$ が渋滞時に対応し，そ れぞれ，自由流領域および停滞流領域とよばれる。自由 流領域では密度の増加と共に交通量も増加するが，停滞 流領域では密度の増加と共に交通量は減少する。なお, $Q-K$ 曲線は道路ごとに異なり, 交通量を実測して得ら れる．以上が高速道路における交通流の非線形特性であ る $[10,11]$.

この非線形特性を踏まえて交通流の動的モデルを作成 する.Fig. 3 に高速道路のモデルを示す．たたし

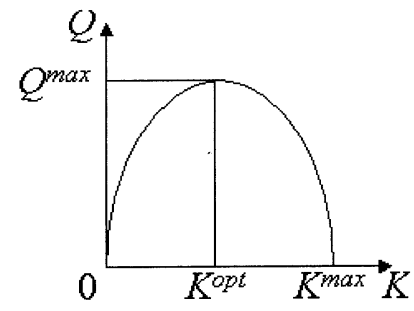

Fig. 1 Traffic density-flow relationship

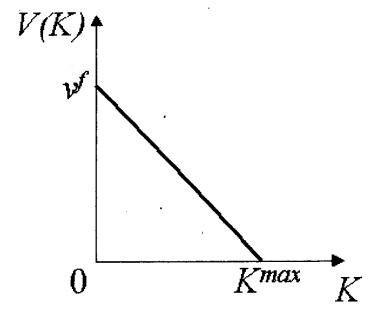

Fig. 2 Traffic density-velocity relationship

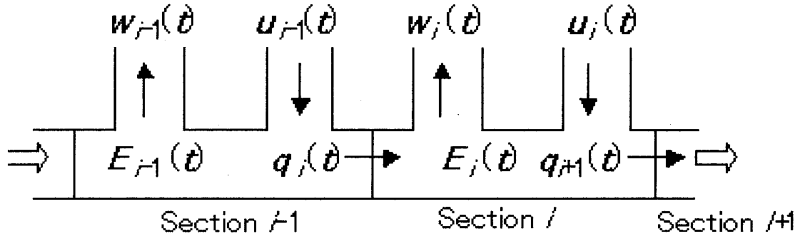

Fig. 3 Expressway divided into sections

$i$ ：対象とする本線を一定長さ（ $L$ とする）で等分割し た区間番号 $(1 \leq i \leq n)$

$E_{i}(t):$ 時刻 $t$ において区間 $i$ に存在する車の台数

$q_{i}(t)$ : 区間 $i$ の最上流地点における時間 $[t, t+1]$ の通過 交通量

$u_{i}(t)$ : 区間 $i$ に含まれる流入ランプからの時間 $[t, t+1]$ の流入交通量

$w_{i}(t)$ : 区間 $i$ に含まれる流出ランプへの時間 $[t, t+1]$ の 流出交通量

である．なお，各区間内には，流入ランプおよび流出ラ ンプはたかだかつあるものとする。

このとき，区間 $i$ 内の時刻 $t+1$ における車の存在台数 は，マスバランスを考慮することにより

$$
E_{i}(t+1)=E_{i}(t)+q_{i}(t)-q_{i+1}(t)+u_{i}(t)-w_{i}(t)(2)
$$

と表すことができる．通過交通量 $q_{i}(t)$ は区間 $i-1$ と $i$ の 境界における密度を $(1)$ 式に用いることにより求められ るが，ここでは，境界密度を区間 $i-1$ の密度 $E_{i-1}(t) / L$ と区間 $i$ の密度 $E_{i}(t) / L$ の重みつき平均で与える。すな わち, $\xi$ を重み係数とすると

$$
q_{i}(t)=Q\left(\frac{\xi E_{i-1}(t)+(1-\xi) E_{i}(t)}{L}\right)(0 \leq \xi \leq 1)
$$

となる。さらに，流出ランプからの流出量 $w_{i}(t)$ は上流 区間からの流入量 $q_{i}(t)$ に比例すると考え

$$
w_{i}(t)=\beta_{i}(t) q_{i}(t) \quad\left(0 \leq \beta_{i}(t)<1\right)
$$

とする。ここに， $\beta$ は流出率とよぶ比例係数で，過去の 流入・流出データから統計的に決定する。(3)，(4) 式を (2) 式に代入すると, 交通流の数式モデルとして

$$
\begin{aligned}
E_{i}(t+1) & =E_{i}(t) \\
+ & +\left(1-\beta_{i}(t)\right) Q\left(\frac{\xi E_{i-1}(t)+(1-\xi) E_{i}(t)}{L}\right) \\
& -Q\left(\frac{\xi E_{i}(t)+(1-\xi) E_{i+1}(t)}{L}\right)+u_{i}(t)
\end{aligned}
$$

を得る，なお，最上流区間では，(5) 式の右辺第 2 項の $Q$ の代わりに，上流側からの流入交通量 $q_{1}(t)$ が与えら れる。 また，最下流区間 $i=n$ では，下流側の存在台数 は不明のため, $E_{n+1}(t)=E_{n}(t)$ と仮定する.

以上によって，初期条件 $E_{i}(0)(i=1,2, \ldots, n)$ ，境界 条件 $q_{1}(t) \quad(t=0,1, \ldots, s-1)$ ，ならびに，流入量 $u_{i}(t)$ 
$(i=1,2, \ldots, n ; t=0,1, \ldots, s-1))$ が与えられれば，各区 間 - 各時刻の存在台数 $E_{i}(t) \quad(i=1,2, \ldots, n ; t=1,2, \ldots, s)$ を求めることができる.

つぎに，本線への流入量に関する制約条件を考える。

$D_{i}(t)$ : 区間 $i$ に接続している流入ランプの時刻 $t$ におけ る車の滞留台数

$U_{i}(t)$ : 区間 $i$ に接続している流入ランプへの時間 $[t, t+1]$ の車の到着台数（需要交通量）

と定義すると, 滞留台数は

$$
D_{i}(t)=\sum_{k=0}^{t-1}\left(U_{i}(k)-u_{i}(k)\right)
$$

と書ける. そうすると, 流入量 $u_{i}(t)$ は滞留台数 $D_{i}(t)$ と 需要交通量 $U_{i}(t)$ の和を超えないことが上限となる。さ らに, 流入量には本線の密度に依存した上限が存在する と考える，すなわち，流入ランプが接続している区間の 密度 $K_{i}(t)$ と単位時間当たり流入可能な交通量 $\phi_{i}(t)$ と の間には, Fig. 4 に示す関係 $\phi_{i}(t)=\Phi\left(K_{i}(t)\right)$ があると 仮定する．ただし， $\phi^{f}$ は本線上に車が走行していない場 合に, 流入ランプから本線へ流入可能な交通量である. 以上から

$$
0 \leq u_{i}(t) \leq \min \left\{\phi_{i}(t), D_{i}(t)+U_{i}(t)\right\}
$$

を得る.なお, 本論文では, $\phi^{f}$ を自由流入交通量, $D_{i}+U_{i}$ を需要流入量とよぶ.

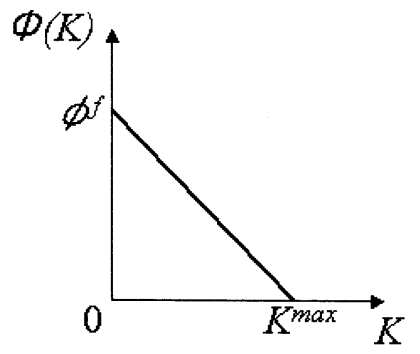

Fig. 4 Traffic density-inflow relationship

\section{2 最適制御問題}

交通流制御の良し悪しを計る評価指標は, 流入量と本 線交通量の和とする．具体的には，(5) 式に基づく将来 交通量の予測期間を $s$ とし, 評価関数 $(f$ とする $)$ を流 入ランプでの滞留台数と本線の通過交通量のトレードオ フとする.

$$
\begin{aligned}
& f=\frac{1-\gamma}{n^{\prime} s} \sum_{i=1}^{n} \sum_{t=0}^{s}\left(1-\frac{D_{i}(t)}{D_{i}^{\text {max }}}\right) \\
& \quad+\frac{\gamma}{n s} \sum_{i=1}^{n} \sum_{t=0}^{s} \frac{\sigma_{i}(t) Q_{i}(t)}{Q_{i}^{\text {max }}} \quad(0 \leq \gamma \leq 1)
\end{aligned}
$$

ただし, $\gamma$ は重み係数, $n^{\prime}$ は流入ランプ数, $D_{i}^{\max }$ は流 入ランプでの可能滞留台数である。また

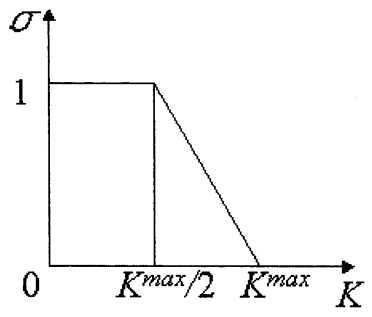

Fig. 5 Traffic density-weight relationship

$$
\sigma_{i}(t)=\left\{\begin{array}{cl}
1 & K_{i}(t)<0.5 K_{i}^{\max } \\
2\left(1-\frac{K_{i}(t)}{K_{i}^{\max }}\right) & K_{i}(t)>0.5 K_{i}^{\max }
\end{array}\right.
$$

である。(9)式は, 渋滞流領域では自由流領域と同じ交 通流量であっても, 評価を厳しく設定することを意味す る. また, 評価関数 $(8)$ 式の右辺第 1 項は, 流入ランプ での滞留台数に比例して評価が下がることを意味する.

以上をまとめると, 流入制御問題は,「制約条件 (5), (7) 式のもとで評価関数 $(8)$ 式を最大にする最適流入量 $u_{i}^{o p t}(t) \quad(i=1,2, \ldots, n ; t=0,1, \ldots, s-1)$ を求める」問題 として定式化できる.

ところで, 交通量の時間変化には月, 曜日, 時間に伴

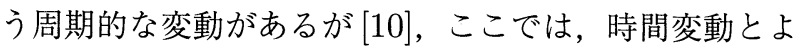
ばれる 24 時間周期の交通量変化を考察の対象とする. 時 間変動とは, 長期間の交通量の時系列データを 1 日ごと の時系列データの集合とみなした場合の集合平均のこと である，後述するように，阪神高速道路の実績デー夕に よれば，集合平均からの偏差の時系列は一様分布に従う 白色雑音に近い。 そこで, 評価関数 (8) 式の計算に必要 となる将来の最上流区間の流入交通量 $q_{1}(t)$ と流入ラン プの需要交通量 $U_{i}(t)$ の予測に過去の実績データの集合 平均を用いることにする。 この設定の妥当性は 5 . で検証 する。

\section{3 最適化問題への変換}

上記非線形最適制御問題は解析的に解くことはできな い. そこで, 定式化した最適制御問題を最適化問題に変 換し，その最適解を探索することによって，元の最適制 御問題の解を数值的に求めることを考える. 具体的には つぎのようになる。制約条件 (7) 式は

$$
0 \leq u_{i}(t) \leq \min \left\{\phi_{i}(t), \sum_{k=0}^{t} U_{i}(k)-\sum_{k=0}^{t-1} u_{i}(k)\right\}
$$

と書ける。これは決定変数の許容領域を逐次的に制限す るものであり，3.で述べる最適解探索方法において，こ の制約条件を満たす変数を生成することは容易である. そこで, 元の非線形最適制御問題を, 決定変数を流入量 $u_{i}(t)(i=1,2, \ldots, n ; t=0,1, \ldots, s-1)$ とし, 制約条件 $(5)$ 式のもとに評価関数 $(8)$ 式を最大化する非線形最適化問 題としてとらえる. そして, 決定变数の許容範囲に関す る逐次的制約条件 (10) 式のもとで, 以下の遺伝的アルゴ リズムに評価関数の最適化探索を行わせる. 


\section{3. 並列適応型遺伝的アルゴリズムによる 探索}

最適解の探索においては，(5) 式の交通流計算の単位 時間ごとに決定変数を設定するのが理想的であるが，変 数の数は膨大なものとなる. その結果, 一変数当たりの 評価值への影響度は小さく, 探索能力が劣る恐れがある. そこで, 変数は単位時間の整数倍 $(m$ とする $)$ ごとに設 定するものとする.すなわち，交通流は離散時間間隔 $\Delta \tau$ ごとに計算するが，そのなかの制御量（流入量）の計算 には $m \Delta \tau$ 時間の間同じ変数値を用いる.

\section{1 染色体表現と解釈}

求める解は $s \times n$ 個の流入量である. 解候補 $u_{i}(t)$ $(i=1,2, \ldots, n ; t=0,1, \ldots, s-1)$ に対応する染色体（個 体）表現を Table 1 に示す. Table 1 は $s^{\prime} \times n^{\prime}$ 長さの 1 次元配列で, $s^{\prime} \times n^{\prime}$ 個の要素 (遺伝子) を $g_{i}\left(t^{\prime}\right) \in[0,1]$ $\left(i=1,2, \ldots, n ; t^{\prime}=0,1, \ldots, s^{\prime}-1\right)$ とする.ただし，簡単 のため $s$ は $m$ の倍数とし, $s^{\prime}=s / m$ である.

Table 1 Expression of chromosomes

\begin{tabular}{|c|c|c|c|c}
\hline Number & 1 & 2 & $\ldots$ & $s^{\prime}$ \\
\hline Gene & $g_{1}(0)$ & $g_{1}(1)$ & $\ldots$ & $g_{1}\left(s^{\prime}-1\right)$ \\
\hline
\end{tabular}

\begin{tabular}{c|c|c|c|c|}
\hline & $s^{\prime}+1$ & $s^{\prime}+2$ & $\ldots$ & $s^{\prime} \times n^{\prime}$ \\
\hline & $g_{2}(0)$ & $g_{2}(1)$ & $\ldots$ & $g_{n}\left(s^{\prime}-1\right)$ \\
\hline
\end{tabular}

解候補は逐次的な不等式制約 (10) 式を満たさなけれ ばならない。そこで，上記遺伝子 $g$ は流入量 $u$ を直接表 現するのではなく, 需要流入量と流入量の比（流入率と いう）を表すものとする.このとき, 遺伝子番号の順に

$$
\begin{aligned}
& u_{i}(t)= g_{i}\left(t^{\prime}\right) \\
& \times \min \left\{\phi_{i}(t), \sum_{k=0}^{t} U_{i}(k)-\sum_{k=0}^{t-1} u_{i}(k)\right\} \\
& m t^{\prime} \leq t<(m+1) t^{\prime}
\end{aligned}
$$

を計算することにより，制約条件 $(10)$ 式を満たす $g_{i}\left(t^{\prime}\right)$ の解表現 $u_{i}(t) \quad\left(m t^{\prime} \leq t<(m+1) t^{\prime}\right)$ を得ることができ る.すなわち, $u$ は必ず実行可能解となる.

\section{2 並列適応型遺伝的アルゴリズム}

提案する並列適応型遺伝的アルゴリズムの手順を Fig. 6 に示す.このアルゴリズムの特徵は, 複数の遺伝的操作 を，単純遺伝的アルゴリズムのように直列的に施すので はなく，並列的かつ適応的に施す点にある.すなわち， 解の探索段階に応じて効果的な遺伝的操作を確率的に多 く施し, 結果として探索効率を上げようとするものであ る. 各処理内容を以下 $(1)-(9)$ に示す.

(1) 初期個体群の生成

初期個体は $[0,1]$ 区間の一様乱数を $s^{\prime} \times n^{\prime}$ 回繰り返 し発生させることによって生成する。この処理を個

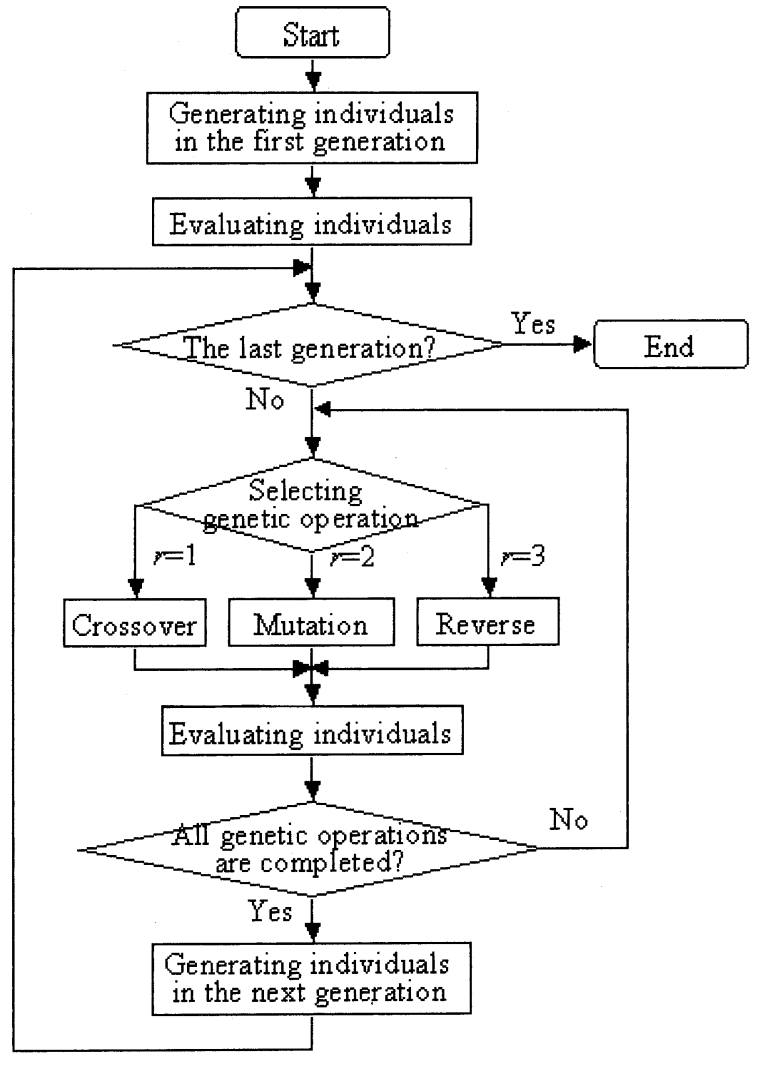

Fig. 6 Flow chart of parallel-adaptive genetic algorithm

体数（ $\alpha$ とする）だけ繰り返し，初期個体群を生成 する。

(2) 適合度評価

染色体の各遺伝子の值を (11) 式で流入量に変換し, (5) 式で存在台数を求める。 その結果を (8) 式に当 てはめ，評価値を算出する。評価值を染色体の適合 度とする，その際，適合度にスケーリングウィンド ウ [13] を導入し, 適合度の少しの差を見かけ上大 きくしてから，遺伝的操作を行う。すなわち，適合 度の最大值を探索する場合，第 $j$ 世代の個体群中の 最小適合度を $f_{\min }(j)$ ，スケーリングウィンドウの サイズを $l$ とし, $F(j)$ を, 過去 $l$ 世代の適合度の最 小值

$$
\begin{aligned}
& F(j)= \\
& \quad \min \left\{f_{\min }(j), f_{\min }(j-1), \ldots, f_{\min }(j-l)\right\}(12)
\end{aligned}
$$

とする。そして, 各個体の適合度 $f(j)$ を

$$
f^{\prime}(j)=f(j)-F(j)
$$

と修正する。この修正適合度は必ず非負となる。こ のように，逐次的に適合度を修正することによって， 集団中の適合度のバラツキが少ない場合でも，ルー レット選択において比較的適合度の低い個体に対す る淘汰圧を強くし，探索効率を高めることができる と期待される。

(3) 停止条件 
繰り返し世代数（世代交代数）があらかじめ定めた 值（Jとする）になれば，繰り返しを終了する。

(4) 操作選択

交叉, 突然変異あるいは逆位の遺伝的操作を確率的 に選択するものとする。 その際, 適合度向上に効果 的な操作を高い確率で選択しょうとするのが操作選 択の狙いである。そのためのアルゴリズムはつぎの 通りである。

各操作（分岐）ごとに親集団と子集団の修正適合度 の平均值を計算し, 各操作の $j-1-j$ 世代間の適合 度向上率を (14)-(16) 式で求める。

$$
\eta_{r}^{j}=\frac{O_{r}^{j}}{P_{r}^{j}}, \quad r=1,2,3
$$

ここに, $O_{r}^{j}$ は操作 $r$ を施して生成した子集団の平均 修正適合度， $P_{r}^{j}$ はその子集団に対する親集団の平 均修正適合度である. $0<\eta_{r}<1$ は操作 $r$ を施した ことにより適合度が悪化したこと， $\eta_{r}=1$ は適合度 に変化なし， $\eta_{r}>1$ は適合度が向上したことを意味 している.この適合度変化のトレンドを指数平滑式

$$
\bar{\eta}_{r}^{j}=\lambda \eta_{r}^{j}+(1-\lambda) \bar{\eta}_{r}^{j-1}, \quad \bar{\eta}_{r}^{0}=1, \quad r=1,2,3(15)
$$

で算出する.ここに， $0<\lambda<1$ である. (15) 式は, $\bar{\eta}_{r}$ が過去 $1 / \lambda$ 世代にわたる $\eta_{r}$ の平均であることを 意味している.そして

$$
s_{r}^{j}=\frac{\bar{\eta}_{r}^{j}}{\bar{\eta}_{1}^{j}+\bar{\eta}_{2}^{j}+\bar{\eta}_{3}^{j}}, \quad s_{r}^{0}=\frac{1}{3}, \quad r=1,2,3
$$

を $j-j+1$ 世代間における操作 $r$ のルーレット選択 確率とする。

(5) 交叉

交叉処理が選ばれると，個体群の中からルーレット 選択により 2 個の親個体を選出する. 選出した 2 個 の親個体の染色体に対して, 一点交叉を適用し, 子 個体を 2 個作り出す. 交叉点は一様乱数を用いて確 率的に決める。

(6) 突然変異

突然変異処理が選ばれると, 個体群の中からルー レット選択により 1 個の親個体を選出する，選出し た親個体の染色体の各染色体に対して, 突然变異率 を介して, 確率的に突然変異を施すかどうかを決め る.そして，突然変異を施す場合は，世代が $j$ のと き, $g_{i}^{j}\left(t^{\prime}\right) \in[0,1]$ に対して, $0-1$ 確率変数 $d$ を導 入して

$$
g_{i}^{j+1}\left(t^{\prime}\right)=\left\{\begin{array}{cc}
g_{i}^{j}\left(t^{\prime}\right)-\delta\left(j, g_{i}^{j}\left(t^{\prime}\right)\right) & (d=0) \\
g_{i}^{j}\left(t^{\prime}\right)+\delta\left(j, 1-g_{i}^{j}\left(t^{\prime}\right)\right) & (d=1)
\end{array}\right.
$$

なる変化を与える．ここに, $\delta(j, \Delta)$ は, $\xi$ を $[0,1]$ の 確率変数, $c$ をパラメータとして

$$
\delta(j, \Delta)=\Delta \xi\left(1-\frac{j}{J}\right)^{c}
$$

で与えられる関数である。これにより，世代 $j$ が進 むと $\delta$ は 0 に近づき, $g_{i}^{j}\left(t^{\prime}\right)$ の微小変化, その結果 として $u_{i}(t)$ の微小变化が期待でき, 詳細な探索が 可能となる $[13]$. なお, 突然变異を施す遺伝子は一 様乱数を使って決める.

(7) 逆位

逆位処理が選ばれると, 個体群の中からルーレット 選択により 1 個の親個体を選出する. 選出した親個 体の染色体に対して，2点を一様乱数を使って確率 的に決め，その間の遺伝子の並びを逆転させる。

(8) 遺伝的操作の適用回数

遺伝的操作の適用回数は子個体の生成数を意味する. したがって, 交叉操作によって生成する子個体数は

2 , 突然変異操作と逆位操作によって生成する子個 体数は 1 である. 子個体の数が一定数（ $\beta$ とする） に達すれば，遺伝的操作の適用を終了する。

(9) 世代交代

$\alpha$ 個の親個体と $\beta$ 個の子個体の和集団（個体数 $\alpha+\beta$ ) のなかで，適合度の高いもの $\alpha$ 個を次世代に残す， いわゆる $(\alpha+\beta)$ 交代 $[14]$ を用いる.

\section{4. リアルタイム制御}

本来，交通流制御問題は無限時間制御問題である。し かし, 問題が解析的に解けない今回の場合, 上記の処理 において予測期間 $s$ を長く設定すると計算量は膨大なも のとなる，その上, 流入ランプの需要交通量と最上流区 間の流入交通量の予測精度は悪くなる。したがって, 流 入制御の実用化を考えると, 短い予測区間の制御問題の 解を制御のタイミングに応じて順次シフトして適用して いくつぎのようなリアルタイム制御の方法が有効と考え られる。

(1) まず, 現時点を $k$ とし, 時刻 $k$ での各区間の車の存 在台数, 時刻 $k$ から $k+p$ までの各流入ランプでの需 要交通量と最上流区間の流入交通量の予測值を使っ て, 時刻 $k$ から $k+p$ までの最適予測制御量の遺伝 子の值 $g_{i}^{o p t}(t)(i=1,2, \ldots, n ; t=k, k+1, \ldots, k+m)$ を求める。ただし， $p$ は $m$ の倍数である.

(2) つぎに，(11) 式で $g_{i}\left(t^{\prime}\right)=g_{i}^{o p t}(k)$ とおいたときの 制御量 $u_{i}^{r e a l}(t) \quad(t=k, k+1, \ldots, k+m)$ を計算し, 時刻 $k$ から $m \Delta \tau$ 時間の間，適用する.

(3) 時刻 $k+m$ になると, 時刻 $k$ から $m \Delta \tau$ 時間の間 の流入ランプでの需要交通量, 流入量および最上 流区間の流入交通量の実績值を (5) 式を使って時刻 $k+m$ の存在台数を計算する. そして, 時刻 $k$ を $k+m$ におきかえて $(1)$ の処理を繰り返す。

予測時間 $p$ の適正值は, 予測時間を順次長くし, 評価 指標が変化しない最短の予測時間とすることで把握でき 
る。また,リアルタイム制御の効果は, 長期間の問題に 対して，2.の予測最適制御を施した場合の評価指標と， 4.のリアルタイム制御を施した場合の評価指標を比較 することで把握できる。これらを，つぎの計算機シミュ レーションで確認する.

\section{5. シミュレーション}

ここでは, シミュレーションによって，評価関数の計 算に必要な将来交通量の予測に実績データの集合平均を 用いることの妥当性, 最適制御の効果, リアルタイム制 御の効果, 並列適応型遺伝的アルゴリズムの有用性, を 検証する。

\section{1 シミュレーションモデル}

阪神高速道路神戸線のデータを参考に, シミュレー ションモデルを設定した.

設定した道路モデルのパラメータはつぎの通りである. 本線道路区間数は $n=20$, 各区間長は $L=1000[\mathrm{~m}]$, 流 入ランプ数は $n^{\prime}=3$ でそれらの区間番号は $i=5,9,14$, 流 出ランプ数は 2 でそれらの区間番号は $i=10,15$ とした. 最大交通量は $Q^{\max }=30[$ 台 $/ \mathrm{min}]$, 最大密度は $K^{\max }=$ 0.125 [台 $/ \mathrm{m}$ ], 自由走行速度は $v^{f}=1666[\mathrm{~m} / \mathrm{min}]$, 各流 入ランプの自由流入交通量はいずれも $\phi^{f}=30[$ 台 $/ \mathrm{min}]$, 各流入ランプの可能滞留台数はいずれも $D^{\max }=100$ [台], 各流出ランプの流出率はそれぞれ $\beta_{10}=0.01, \beta_{15}=0.02$ とした。

つぎに，交通量のモデルを設定するために，実績デー 夕の統計的性質を調べた。その結果，長期間の交通量の 時系列データを 1 日ごとの時系列データの集合とみなし た時，集合平均からの偏差の時系列は一様分布をする白 色雑音に近いことが分かった。そこで，評価関数の計算 に必要となる将来交通量の予測值として過去の実績デー 夕の集合平均を用いることにした。 そして，シミュレー ションの対象は渋滞が発生する時間帯を含む 4 時から 13 時までの 9 時間とし, 時刻 $T[\mathrm{~min}]$ における各流入ラン プの需要交通量，最上流区間の流入交通量の平均值をつ ぎのように設定した。

$$
\begin{aligned}
& U_{5}(T)=U_{14}(T)= \\
& \left\{\begin{array}{lr}
0.125 \times T / 60 & 0 \leq T<240 \\
0.5 & 240 \leq T<300 \\
0.5-0.125 \times(T-300) / 60 & 300 \leq T<420 \\
0.25 & 420 \leq T
\end{array}\right.
\end{aligned}
$$

$U_{9}(T)=$

$$
\left\{\begin{array}{lr}
0.3125 \times T / 60 & 0 \leq T<240 \\
1.25 & 240 \leq T<300 \\
1.25-0.3125 \times(T-300) / 60 & 300 \leq T<420 \\
0.625 & 420 \leq T
\end{array}\right.
$$

$q_{1}(T)=$

$$
\left\{\begin{array}{lr}
1.5625 \times T / 60 & 0 \leq T<240 \\
6.25 & 240 \leq T<300 \\
6.25-1.6667 \times(T-300) / 60 & 300 \leq T<420 \\
2.9167 & 420 \leq T
\end{array}\right.
$$

偏差は平均值の \pm 0.5 倍の範囲で一様分布する白色雑 音とし，平均值に偏差を付加したものを実績值に擬した。 Fig. 7 に需要交通量の平均值を示す.

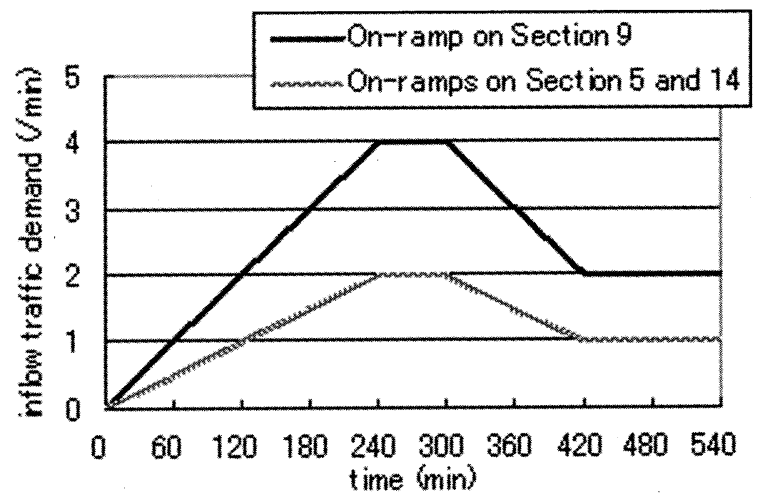

Fig. 7 Traffic demand on each on-ramp

また，離散時間間隔は $\Delta \tau=0.25[\mathrm{~min}]$ とした。さら

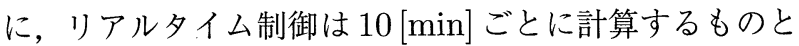
した。したがって， $m=10 / 0.25=40$ となる。

\section{2 最適制御量探索の効率化}

(19)-(21) 式で与えられる予測值に対して, 需要交通 量が比較的少なく，極端な渋滞が発生しないと考えられ る $T \leq 270[\mathrm{~min}]$ の範囲では流入率を $g_{i}(t)=1$ と設定し て (1)，(5) 式に基づき交通流シミュレーションを行い, その結果を初期值とする $270[\mathrm{~min}] \leq T<390[\mathrm{~min}]$ の範 囲の交通流に対して最適制御量 $u_{i}^{o p t}(t)$ の探索を行った. 遺伝的アルゴリズムのパラメータは，親個体数を $\alpha=50$, 子個体数を $\beta=\alpha / 2$, 最大世代数を $J=500$, 評価関数 (適合度) の重み係数を $\gamma=0.7$, スケーリングウインド ウのサイズを $l=10$, 指数平滑の係数を $\lambda=0.2$, 突然変 異率を 0.1 , 微小变異の指数を $c=1$ とした.

提案した探索アルゴリズムの適応能力を把握するため に，まず，遺伝的処理の選択確率 $s$ (16) 式で与えた場合 と常に $s_{r}^{j}=1 / 3$ に固定した場合を比較した．また，最適 制御の効果を把握するために，270[min] $\leq T<390[\mathrm{~min}]$ の範囲でも流入率を $g_{i}(t)=1$ と設定した場合すなわち制 御を施さない場合も計算した。

流入率を $g_{i}(t)=1 \quad(270[\mathrm{~min}] \leq T<390[\mathrm{~min}])$ に固定 した場合の $270[\mathrm{~min}] \leq T<390[\mathrm{~min}]$ の範囲の評価関数 値を $f_{g}$, 提案手法の場合の評価関数値（最大適合度）を $f_{a}$, 選択確率を固定した場合の評価関数值（最大適合度） を $f_{f}$ とし, 比

$$
\rho_{a}=\frac{f_{a}}{f_{g}}, \quad \rho_{f}=\frac{f_{f}}{f_{g}}
$$

を探索効率と制御性能を合わせた評価指標とした. Fig. 8 
に10 回試行した指標の平均值を示す. 約 70 世代以降で $\rho_{a}>\rho_{f}$ となっている.すなわち, 提案手法によれば短 い世代で評価の良い解を得ることができる。つぎに, 突 然変異の微小变化機能の効果を確認するために, (18) 式 において $c=0$ とした場合を試行した. 他の条件は前述 の試行と同様である.Fig. 9 に 3 回試行した指標 $\rho_{a}$ の平 均值を示す. 同図には, $\alpha=30, c=1$ の場合も併せて示 してある.いずれの個体数でも, 約 50 世代以降で $c=1$ の場合の指標が大きく, 微小变異の有効性が確認できる.

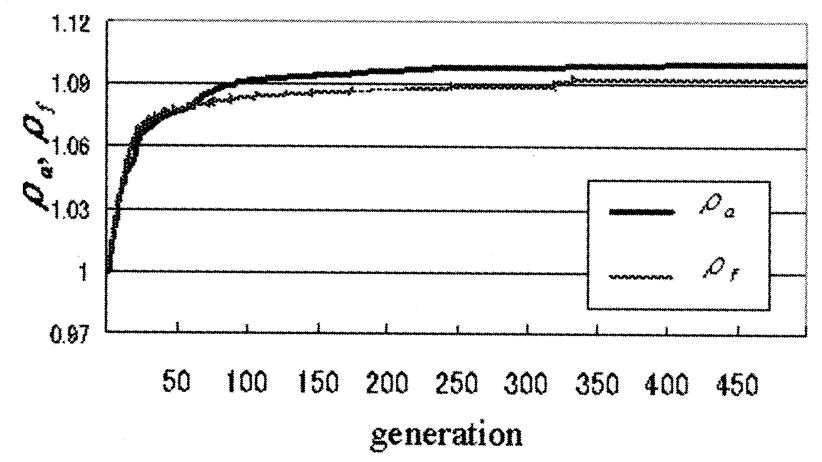

Fig. 8 Effect of adaptive selection of genetic operators

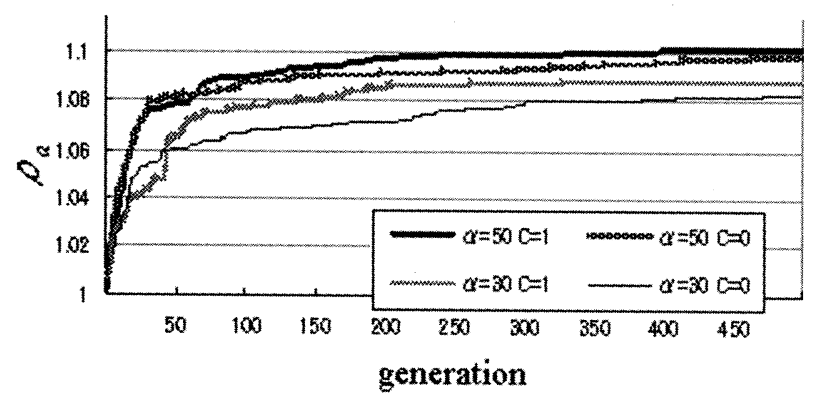

Fig. 9 Effect of fine-mutation

\section{3 最適制御の効果}

Figs. 8,9 は最終的な評価指標の值は $\rho_{a}=1.10$ 程度で あることを示している。これから，需要交通量が多い場 合，流入量制御をすると制御をしなかった場合に比べて 評価值は約 10 \%向上することがわかる.この值の意味 するところを詳しく見るために, Fig. 10 に時間帯別の指 標値を示した，制御時間帯の最初の部分で指標值は小さ く, 以降の時間帯で大きくなっている. そして, 指標值

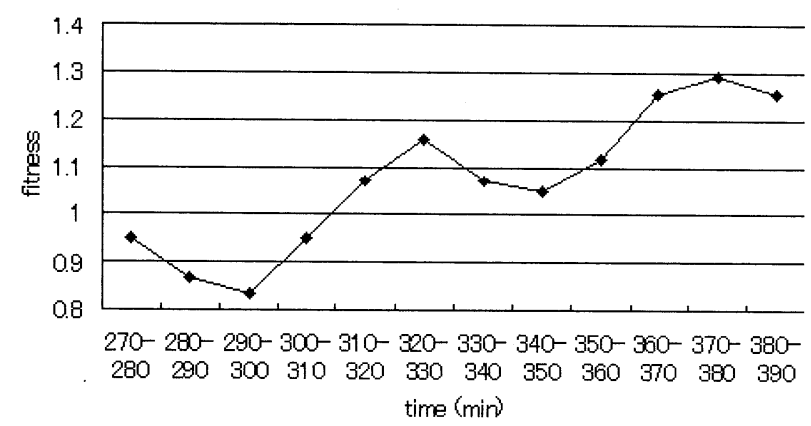

Fig. 10 Performance of each time
の時間平均が制御の有無の差 $10 \%$ となる。指標値の時間 的変化は，まず，流入ランプからの流入量を抑えて本線 上の存在台数を少なくして抒き, 以降の極端な渋滞発生 に備えていることを意味していると考えられる。これか ら，極端な渋滞が発生しやすい時間帯ほど制御は効果的 であることが分かる。

\section{4 将来交通量の予測}

評価関数の計算に必要な将来交通量の予測值に過去の 実績データの集合平均を用いることの妥当性を検証した。 まず，5.2節と同様に，需要交通量が少なく，渋滞が発 生しないと考えられる $T<270[\mathrm{~min}]$ の範囲で流入率を $g_{i}(t)=1$ と設定して交通流シミュレーションを行った. ただし，需要交通量には実測值を用いた。そして，その 結果を初期値とする $270[\mathrm{~min}] \leq T<390[\mathrm{~min}]$ の範囲の 交通流に対して予測最適制御量 $u_{i}^{o p t}(t)$ の探索を行った. 需要交通量には予測值を用い，また，遺伝的アルゴリズ ムのパラメータは 5.2 節と同様とした. 10 回試行した ときの評価指標の平均值は $\rho_{a}=1.097$ であった。なお, 最適流入率を実績需要交通量に対して適用した場合の評 価指標の平均值は $\rho_{a}=1.082$ であった。これは予測值に 対して得られた值の $1 \%$ 程度の差でしかない.したがっ て, 交通流制御問題に対しては, 線形二次形式制御問題 の場合ような確定等価原理は成り立たないが, 将来の流 入交通量と需要交通量という不確定量の予測に過去の実 績データの集合平均を用いても制御量の算出に実用上支 障はないと考えられる。

\section{5 リアルタイム制御の効果}

リアルタイム制御に扔ける予測時間を変化させ，制 御効果を比較することにより, 予測時間の適正値を検討 した. 予測時間として $p=60,50,40,30,20,10[\mathrm{~min}]$ の 6 通りを考え，上記と同様に $270[\mathrm{~min}] \leq T<390[\mathrm{~min}]$ の 範囲の交通流に対してリアルタイム制御量 $u_{i}^{r e a l}(t)$ の探 索を行い, 評価指標を求めた。結果を Table 2 に示す. $p=60,50,40,30[\mathrm{~min}]$ の場合の評価指標はほとんど同じ である.また, 評価指標の平均值も予測最適制御の場合 と大きな違いはない。これらの結果から, 交通流制御は 短時間先までの予測制御でほほ有効な結果が得られ，予 測時間としては $p=30[\mathrm{~min}]$ が適当と考えられる. Fig. 11 にリアルタイム制御を適用した場合と制御を行わなかっ た場合の三つの流入ランプに扔ける滞留台数の総和の経 時変化を比較して示す.また，Fig. 12 に区間 14 の存在 台数の経時変化を示す. 本線交通流に対しても, リアル タイム制御の有効性が確認できる.

\section{6. あとがき}

本論文では，交通流を非線形動的システムとして取り 扱った高速道路流入制御問題を考え, その数值解法につ いて検討した，得られた結果はつぎのようである。

(1)最適制御問題の解法として, まず, 問題を離散時間型 
Table 2 Prediction interval and performance of real-time control

\begin{tabular}{|c||c|c|c|}
\hline & $10[\mathrm{~min}]$ & $20[\mathrm{~min}]$ & $30[\mathrm{~min}]$ \\
\hline \hline $270-280$ & 0.9877 & 0.9855 & 0.9729 \\
\hline $280-290$ & 0.9830 & 0.9766 & 0.9722 \\
\hline $290-300$ & 0.9889 & 0.9979 & 1.0479 \\
\hline $300-310$ & 0.9869 & 1.0201 & 1.0840 \\
\hline $310-320$ & 1.0096 & 1.0583 & 1.1212 \\
\hline $320-330$ & 1.0235 & 1.0890 & 1.1443 \\
\hline $330-340$ & 0.9391 & 0.9771 & 1.0507 \\
\hline $340-350$ & 0.9524 & 0.9525 & 1.0345 \\
\hline $350-360$ & 1.0225 & 0.9778 & 1.0920 \\
\hline $360-370$ & 1.1030 & 1.0883 & 1.2106 \\
\hline $370-380$ & 1.0878 & 1.1418 & 1.2371 \\
\hline $380-390$ & 1.0550 & 1.1291 & 1.1895 \\
\hline \hline Average & 1.0116 & 1.0328 & 1.0964 \\
\hline
\end{tabular}

\begin{tabular}{|c||c|c|c|}
\hline & $40[\mathrm{~min}]$ & $50[\mathrm{~min}]$ & $60[\mathrm{~min}]$ \\
\hline \hline $270-280$ & 0.9687 & 0.9679 & 0.9555 \\
\hline $280-290$ & 0.9420 & 0.9352 & 0.9128 \\
\hline $290-300$ & 1.0350 & 1.0414 & 0.9991 \\
\hline $300-310$ & 1.0913 & 1.0861 & 1.0733 \\
\hline $310-320$ & 1.1255 & 1.1145 & 1.1305 \\
\hline $320-330$ & 1.1692 & 1.1790 & 1.1771 \\
\hline $330-340$ & 1.0650 & 1.0914 & 1.1081 \\
\hline $340-350$ & 1.0656 & 1.0555 & 1.0812 \\
\hline $350-360$ & 1.1126 & 1.0941 & 1.1266 \\
\hline $360-370$ & 1.2497 & 1.2331 & 1.2315 \\
\hline $370-380$ & 1.2700 & 1.2511 & 1.2238 \\
\hline $380-390$ & 1.2175 & 1.2213 & 1.2298 \\
\hline \hline Average & 1.1093 & 1.1059 & 1.1041 \\
\hline
\end{tabular}

非線形最適制御問題として定式化し，つぎに，非線形最 適化問題としてとらえ直すことにより，流入ランプでの 最適流入量の数值解を探索するという方式を提案した. その際, 将来交通量という不確定量の予測に過去の実績 交通量の集合平均を用いた。阪神高速道路のデー夕を参 考にしたシミュレーションで制御の効果を検証したとこ ろ, 将来交通量の予測に集合平均を用いることの妥当性 が確認でき，また，制御を行わない場合と比較して評価 值は平均的に 10 \%向上すること, 需要交通量が多く, 渋 滞が発生するような場合に制御の効果が顕著であること, が分かった。

(2)実用的なリアルタイム制御方式も併せて提案した。 ミュレーションの結果, 30 分先までの交通量を見込んだ 最適制御を 10 分ごとに行うことで, 長時間 (120分) 先 までの交通量を見込んだ最適制御を行った場合とほほ同

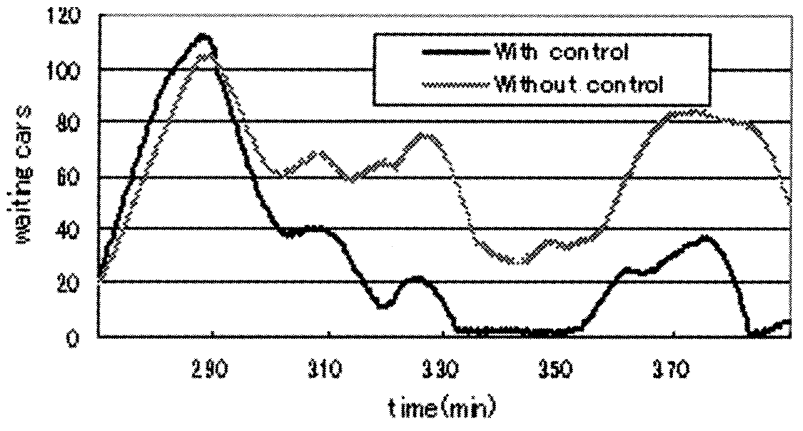

Fig. 11 Simulation of total amount of waiting cars

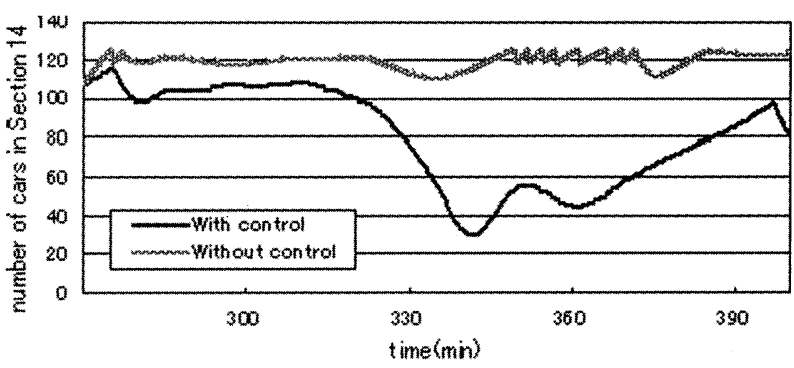

Fig. 12 Simulation of number of cars in Section 14

等の評価が得られることが分かった.

(3)最適制御㧍よびリアルタイム制御で用いる最適化手法 として, 効果的な遺伝的操作を適応的に施す並列適応型 遺伝的アルゴリズムを提案した. 提案したアルゴリズム を用いると世代数が比較的小さいうちに評価の良い解が 得られることが, シミュレーションによって確認できた。 これは, 計算時間の短縮を意味し, リアルタイム制御に は有用である。

実際の高速道路は距離が長く, 車線数が途中で変化す る場合もある。また，交通流にはパーキングエリアで の一時的な駐車に伴う車の消滅, 発生などの現象もあ る。したがって, 実際の交通流制御問題は大規模かつ複 雑である。ささらに, 都市部での導入が期待されている TDM (Traffic Demand Management: 交通需要マネジ メント）の高速道路上での実現手段の一つとして, 混雑 具合に基づく変動型利用料金設定による需要制御への対 応などが考えられる. 今後, 交通流制御の実用化に向け て, 本論文で提案した最適化手法にルールベース制御や シミュレーションを融合したような方法論を検討してい く必要があると考える。

\section{参考文献}

[1] J. A. Wattleworth: Peak period analysis and control of a freeway system; Highway Research Record, No. 157 , pp. 1-10 (1967)

[2] 佐々木, 明神：都市高速道路網に抢ける流入制御理論； 交通工学, Vol. 3, No. 3, pp. 8-16 (1968)

[3] J. J. Wang and A. D. May: Computer model for optimal freeway on-ramp control; Highway Research Record, No. 469, pp. 16-25 (1973) 
[4] C. I. Chen, J. B. Gruz Jr. and J. G. Paquet: Entrance ramp control for travel rate maximization in expressways; Transportation Research, Vol. 8, pp. 503-508 (1974)

[5] 明神, 坂本, 岩本 : 流入待ち行列を考慮した LP 制御 ; 交通工学, Vol. 10, No. 4, pp. 15-23 (1975)

[6] L. S. Yuan and J. B. Kreer: Adjustment of freeway ramp metering rates to balance entrance ramp queues; Transportation Research, Vol. 22, pp. 127$133(1988)$

[7] 朝倉, 柏谷, 山内：観測データの利用による都市高速道 路の動的な LP 型流入制御モデル ; 土木計画学研究・論 文集，No. 13，pp. 923-931（1996）

[8] 楊, 飯田, 宇野: 走行速度の時間変化を考慮した動的 LP 制御モデル ; 土木学会論文集, No. $597 / \mathrm{IV}-40$, pp. 113-126 (1998)

[9] 下浦, 天目 : 動的ランプ流入制御方式の高度化; 電気学 会研究会資料（交通・電気鉄道，道路交通合同研究会）, pp. 57-62 (1999)

[10] 佐々木（監修），飯田（編著）: 交通工学 ; 国民科学社 (1992)

[11] P. Kachroo and K. Ozbay: Feedback Control Theory for Dynamic Traffic Assignment, Springer (1999)

[12] 森地, 清水: 都市高速道路における新たなリアルタイム 流入制御手法に関する研究一遺伝的アルゴリズムの適 用一; 土木計画学研究・論文集, No. 13, pp. 915-922 (1996)

[13] Z. Michalewicz: Genetic Algorithms + Data Structures = Evolution Programs, 3rd Rev Edition, Springer (1996)

[14] T. Back, F. Hoffmeister and H. -P. Schwefel: A survey of evolution strategies; Proceedings of the Fourth International Conference on Genetic Algorithms, pp. 29 (1991) 